\title{
Ellipsis
}

Volume 44

Article 16

2017

\section{My Mother's Clothesline}

M. M. Kaufman

Follow this and additional works at: https://scholarworks.uno.edu/ellipsis

\section{Recommended Citation}

Kaufman, M. M. (2017) "My Mother's Clothesline," Ellipsis: Vol. 44 , Article 16.

DOI: https://doi.org/10.46428/ejail.44.16

Available at: https://scholarworks.uno.edu/ellipsis/vol44/iss1/16

This Poetry is brought to you for free and open access by the Department of English and Foreign Languages at ScholarWorks@UNO. It has been accepted for inclusion in Ellipsis by an authorized editor of ScholarWorks@UNO.

For more information, please contact scholarworks@uno.edu. 


\section{My Mother's Clothesline}

M. M. Kaufman

Vassar Miller Poetry Award Honorable Mention

I lie with my siblings underneath the clothesline pulled taut between two wooden posts.

We count the stains mother couldn't wash out. Sins we keep secret when she's gone and he asks

questions. I am the one who accepts

dares and climb a post that shouldn't hold

my weight, but here I am. The others throw

marbles, hit the back of my head. Laundry

falls, piece by piece, into the breathless ether.

I climb the clothesline until I reach

Cassiopeia in her throne. I take her

shape; $W$ is for woman, for where.

She takes my hands and spins

me upside down in her orbit; $M$ is for mother,

for monster. Keep me as your daughter of the stars. I do not want to go back to where my mother

tells lies like she washes clothes. Cassiopeia lets go. I fall through her hair, through the stars, and land

in the washing. The clothesline wrapped around me, binds me to the lawn. Hung out and dried, stains set. 